Meta

Journal des traducteurs

Translators' Journal

\title{
Towards a Taxonomy for the Study of Translation
}

\section{Steven Tötösy de Zepetnek}

Volume 40, numéro 3, septembre 1995

La traduction, qu'est-ce à dire? Phénoménologies de la traduction

URI : https://id.erudit.org/iderudit/004641ar

DOI : https://doi.org/10.7202/004641ar

Aller au sommaire du numéro

Éditeur(s)

Les Presses de l'Université de Montréal

ISSN

0026-0452 (imprimé)

1492-1421 (numérique)

Découvrir la revue

Citer cet article

Tötösy de Zepetnek, S. (1995). Towards a Taxonomy for the Study of

Translation. Meta, 40(3), 421-444. https://doi.org/10.7202/004641ar
Résumé de l'article

Cet article propose une taxinomie pour l'étude de la traduction. Les bases théoriques en sont l'œuvre d'Anton Popovit (notamment son Dictionary for the Analysis of Literary Translation, 1976), la théorie du polysystème, ainsi que la théorie systémique et empirique. Le but en est d'offrir un cadre opératoire et fonctionnel afin d'étudier la traduction considérée comme un acte de communication au sein de la communication littéraire, elle-même considérée comme un sous-système de la communication sociale. 


\title{
TOWARDS A TAXONOMY FOR THE STUDY OF TRANSLATION
}

STEVEN TOTOSY DE ZEPETNEK

University of Alheria. Edmonton. Canada

\begin{abstract}
Résume
Cel article propose une taxinomie pour l'étude de la traduction. Les hases théoriques en sont l'auvre d'Anton Popovic (notamment son Dictionary for the Analysis of Literary Translation, 1976). la théorie du polysystème, ainsi que la théorie systémique et empirique. Le but en est d'offrir un cadre operatoire et fonctionnel afin d'etudier la traduction considérée comme un acte de communication au sein de la communication littéraire, elle-méme considérée comme un sous-systeme de la communication sociale.
\end{abstract}

\section{INTRODUCTION}

Translation theory continues to attract the interest of both scholars and active translators and new works - from a wide range of theoretical and methodological points of view - are being published with increasing frequency. However, among the publications dealing with translation theory few contain operational and functional frameworks. In other words, there is little discussion involving the notion of tools for the study of translation.

The late Anton Popoviz. Professor at the Pedagogical Faculty of Nitra and at the Research Centre of Translation Studies, Comenius University (Bratislava), was distinguished Visiting Professor at the University of Alberta Department of Comparative Literature in 1975-1976. After his visit at the University of Alberta, he published in mimeographic form with the University of Alberta Department of Comparative Literature his Dictionary for the Analysis of Literary Translation in 1976. In light of recent developments in translation studies and literary theory and the continuous interest in Popovic's Dictionary, it is evident that Popovic's work maintained its scholarly merit. For example, Dinda L. Gorlée states in her new book. Semiotics and the Problem of Translation (1994: 18) that Popovič's Dictionary is an "influential typescript" and André Lefevere, in his Translating Literature, refers to the importance of Popovic's influence on EvenZohar's Polvsystem Theory (1992: 11). Previously. Edward Możejko's 1979 article, "Survey: Slovak Theory of Literary Communication - Notes on the Nitra School of Literary Criticism" explains in more detail the basic tenets of Popoviz's work (see Możejko again in 1993 and Agostino Visco's recent discussion of the Nitra School).

What is striking in all the explanations of and references to Popovic 's work is the "systemic" theoretical and methodological implication. More, the systemic base is reinforced by a perspective of operationality and functionality. While this is less evident with reference to the Polysystem Theory - which is leaning towards a socio-semiotic perspective (cf. Even-Zohar; Dimić and Garstin; Dimic;; Gorp 199lb) - the notions of system and operationality become more clear when Popovič $s$ work is brought into contact with the Systemic and Empirical Approach to Literature. In other words, what was until now occurring by implication only. will be presented explicitly. This systemic and (radical/cognitive) constructivist-empirical framework and methodology was developed and is being continously developed by Siegfried J. Schmidt and his group at Siegen University and elsewhere (see, for example, Schmidt 1982b. 1991, 1994: Segers; Tötösy $1992,1993,1994 \mathrm{c})$. It is a framework and methodology where literature is viewed as a 
"soft" sub-system of the system of social communicative interaction and where operational and functional aspects of methodology are stressed (cf. e.g., Barsch et al.; Gorp 1991a; Rusch and Schmidt: Schmidt 1980, 1982a, 1982b, 1991, 1992; Tötösy 1992. 1993: Wilpert; for bibliographies and a synthesis of systemic approaches to literature of Tötösy 1992 and 1994a). It is also noteworthy that the systemic and empirical approach is increasingly being recognized in literary studies in general. This can be seen, for example, in the recent English translation of Yves Chevrel's Comparative Literature Today: Metheds \& Perspective's (1995) (for its application in Applied Cultural Studies, see Tötösy 1994b).

Based on the conceptual relationship between Popovičs Dictionary, the Polysystem Theory, and the Systemic and Empirical Approach to Literature (SEAL), this taxonomy is presented - following the systemic and constructivist postulate of operationality - as an instrument of translation studies. Briefly put: according to Popovic, translation is a communicative act performed in the system of literary communication. Similarly, in the SEAL framework literary communication is a polyvalent (and aesthetic) sub-system of the system of social communicative interaction. This sub-system is operationally and functionally conceptualized in the categories of the 1) Text and Producer (Produktionsbereich); 2) the Processing of the Text (Vermirtlungshereich); 3) the Reception and Receivers of the Text (Rezeptionshereich): and 4) the Post-Production Processing of the Text and Producer, e.g., literary criticism, the academic sphere including the teaching of literature, etc. (Verarbeitungsbereich). The elements and factors of translation in the system of literary communication can he found in all four basic systemic categories. Corresponding to the four SEAL categories are the following factors of the translation processes and mechanisms:

1) $\mathrm{TT} 1=$ The Text to Be Translated;

2) $\mathrm{TT} 2=$ The Translated Text:

3) $\mathrm{TPI}=$ The Producer of the Text to be Translated:

4) $\mathrm{TP} 2=$ The Producer of the Translated Text;

5) $\mathrm{PTI}=$ The Processing of the Text to Be Translated:

6) PT2 = The Processing of the Translated Text;

7) $R R 1=$ The Reception and/or Receivers of the Text to Be Translated;

8) $R R 2=$ The Reception and/or Receivers of the Translated Text;

9) $\mathrm{PPI}=$ The Post-Production Processing of the Text to Be Translated:

10) PP2 = The Post-Production Processing of the Translated Text;

11) $\mathrm{CS}=$ Communicating Suhject. $\mathrm{CS}$ is defined as a communicating participant in $\mathrm{TT} 1$ to PP2, wherein his/her function is the transmission of a specific message carried in TT2.

\section{TAXONOMY}

\section{* ACTUALIZATION OF TRANSLATION}

The TP2's modification(s) of TT1 in relation to the time of the TTI's topic, theme, or action, based on the TP2's perception of the RR2's communicative perspectives of the literary system and/or hased on demands PP2's which is, as well, expressed in the RR2's cultural-literary environment.

\section{* ADAPTATION OF TRANSLATION}

The TP2's modification(s) of TT1 in its self-referential relation to its own topic or theme and its elements, its protagonists, and cultural specificities. The adaptation takes into account selectively or in totality the demands of the above ten SEAL categories. 


\section{* ADEQUACY OF TRANSLATION see STYLISTIC EQUIVALENCE \\ * ARCHISEME}

The basic functional semiotic unit of primary importance that is realized by various semantic units upon which the meaningful level of the aesthetic (poetic) text is built (Lotman). In translation. the archiseme is attached to invariant components of TT1, i.e. the archiseme facilitates the transfer of the TT1's deep structure to TT2's semiotic level.

\section{* ARCHITEXT}

The ideal construction of TT1 that serves as a basis for the meta-textual link. The notion of Architext is especially applicable in folklore theory where it may be used to illustrate the process of variation.

\section{* ATTITUDE(S) OF TP2 TOWARDS TTI}

1. Communicative Altitude

The TP2's standpoint while coding and decoding the TT1 message. In the act of literary communication the TP2 participates in decoding the TT1 message, i.e. the process of translation includes and analytical phase (the decoding of TTI) and a synthetic phase (the coding of TT2), together resulting in TT2. The synthetic phase also includes the TP2's effort to achieve a diversified level of literary communication that manifests itself in the text as a dynamic configuration of certain expressive features, i.e. the re-coding of cultural, genre. gender, historical, etc., content, expression, and style.

2. Confrontation of Communicative Attitudes in Translation

The TP2's consideration of RR2 and/or PP2. This consideration may or may not result in complience with the expectations of RR2 and/or PP2. The considerations may include expression and/or style.

3. Ideological Attitude

The TP2's attitude to the ideological and aesthetic/poetic qualities of TT1, reflecting the literary communicative demands of his/her society in toto - i.e. depending on variables in TT1, the sum of all SEAL categories or some but not all categories - as well as her/his own conception of literary communicative interaction.

4. Stylistic Attitude

TP2 $\mathrm{s}$ attitude to the stylistic features of TT1. This attitude is a result of influences by the prevailing mechanisms and dialectic of the literary system, as well as by TP2's tendencies towards stylistic features or factors. Three types of this attitude can be distinguished: 1) the zero attitude - results in a TT2 that is stylistically colourless; 2 ) the redundant attitude - means that stylistic characteristics are warranted only in relation to properties of language by the exclusion of aesthetic/poetic characteristics; and 3) a new style is developed by TP2 for TT2 ( $f$. Balcerzan).

\section{* AUXILIARY MODEL OF TRANSLATION see LANGUAGE (MEDIATING LANGUAGE} IN TRANSLATION)

\section{* AXIOLOGY OF TRANSLATION}

The Axiology of Translation is the formulation of the value of TT2. Value-theory criteria are set by PP1 and/or PP2 for TP2. PP1 and/or PP2 are active in postulating these values through their systemic mechanisms and dialectics. Of imponance is the resolution of the tension between the postulates of PP1 and/or PP2 and the aesthetic/poetic expectations of RR2. Three basic mechanisms occur in the validation of TT2 in PP2: 1) criticism aiming at the evaluation of TT2 from the viewpoint(s) of RR2:2) a comparison of the TT2 with the TTI by the interrelation of the realization of the intellectual. cultural, historical, etc. and aesthetic/poetic values of TT1 in TT2; and 3) the intellectual, literary historical, cultural, etc., and aesthetic/poetic place of TT2 in the context of RR2. 


\section{* CODES}

1. Mediating Code in Translation see Language (Mediating Language in Translation)

2. Stylistic Code

The Stylistic Code consists of a system of factors serving to generate the expressive structure of the text. It includes the range of basic expressive qualities and the rules of their functioning in $\mathrm{T} T 2$.

3. Dialogue Between Translator and Editor

Dialogue between the level of aesthetic polyvalence of TP2 and those of the editor. The editor, as part of PT2, embodies values and characteristics developed and/or prescribed by the publishing institution she/he represents and/or certain cultural policies. Thus, the editor is an executor of literary and linguistic standards for TT2.

* COMMUNICATIVE DIMENSIONS IN THE PROCESS OF TRANSLATION

The range of literary communicative possibilities in the process of translation resulting from the fact that the act of translation is a juxtaposition of two literary communicative sub-systems: TP1 - TT1 - PT1 - RR1 - PPI and TP2 - TT2 - PT2 - RR2 PP2. It is evident that some temporal as well as spatial shifts take place during this systemic literary communicative interaction.

\section{* COMMUNICATIVE SITUATION}

The interaction set up between the communicants of the literary communicative system (TT1 to PP2) during the process of translation.

* CONTEXT

1. Confrontational-Creative Contert see Meta-Communicational Context of Translation

2. Meta-Communicational Conte.t of Translation

A secondary literary context allowing the reproduction of invariant features of the TT1 and their modification in the translation upon the basis of the functional principle. This functional principle is termed Confromational-Creative Context of translation. It involves the capacity of the TT1 to produce a new communicational context of a reproductional and modificational nature.

3. The Overlaping of Cultural Code's in Translation

The Overlapping of cultural codes of TT1 and TT2 in TT2. The overlap functions as an exponent of the two respective cultures.

* cultural Gap in translation

Communicative difference(s) between TT1 and TT2. It results from temporal and/or spatial and knowledge-based differences between the cultural/historical context of TTI and that TT2. The cultural/historical codes of TT1 may or may not coincide in its intensity most frequently it does not - with the cultural code realized in TT2. This means a retarded or - rarely — an accelerated development of the cultural/historical codes from TT1 into TT2.

\section{* CULTURALIHISTORICAL CODES}

1. "Domestic" CulturallHistorical Codes in Translation

Thematic, linguistic, and stylistic elements in TT2 which represent TP2's cultural as well as literary affiliation(s) and also express RR2`s preferences and/or prejudices.

2. "Foreign" Cultural/Historical Code's in Translation

Thematic, linguistic, and stylistic elements in TT1 which are "carriers" of the cultural/historical codes in TTI. These may or may not serve as informative examples of the evolution of the "Domestic" Culturall Historical Codes.

3. Cultural/Histerical Code Peculiarities

Elements of the "Domestic" Cultural/Historical Codes realized in TT1. These may or may not be carried into TT2. 


\section{* DISCOVERY OF A NEW STYLE IN TRANSLATION}

The realization of stylistic and semantic invariants of TT1 in TT2 which enrich the domestic style and stylistic tradition with hitherto unknown and/or new elements (Etkind).

\section{* DIVERGENCE BETWEEN THE PERCEPTION OF TTI AND TT2}

Communicative differences resulting from the fact that there are temporal and cultural demarcations between the communication of TT1 and that of TT2 and which are notable for their different communicative qualities.

\section{* DOMESTIC STYLISTIC SUPERSTRATUM IN TRANSLATION}

The Impact of the expressive conventions of the language of TT1 upon TT2. The measure of this stylistic superstratum is determined by the elaborateness of the conventions of the expressive repertory of the domestic literature and the TP2's expressive idiolect. The stylistic superstratum is identified by RR2 to an extent determined by his/her level of sophistication.

\section{* eDITOR of TRANSLATION}

Participant in PT1 and/or PT2 whose measure of participation is relevant to the production of TT2. This means that the editor's implicit or explicit points of view in relation to factors of the literary system. e.g. cultural policy, literary situation, the publisher's demands, etc., are influential to the form and content of TT2. As well, the editor may take part in the selection of TP2.

\section{* EQUIVALENCE IN TRANSLATION}

1. Linguistic Equiralence in Translation

Homogeneity of elements upon the linguistic (lexical, phonetic, morphological, and syntactic) levels of TT1 and TT2 converge. Homogeneity upon which the linguistic levels are based and which interconnect by determining equivalence at the expressive level of TT 1 and TT2

\section{Paradigmatic Equivalence in Translation}

Equivalence of the elements of a paradigmati-expressive axis, upon which the stylistic level is built as a configuration of expressive elements. This equivalence is markedly different from Linguistic Equivalence, as it is of a higher category of style.

3. Stylistic Equivalence in Translation

Equivalence of elements in function in both TT1 and TT2, aiming at an expressive identity under invariance of identical meaning.

4. Tertual (Syntagmatic) Equivalence

Arrangement of the elements upon the syntagmatic axis of TT1. The axis is conditioned by TP2 $s$ levels of expressive feeling, provided there is a freedom of choice of expressive means from the paradigmatic "stock" of style, the expressive level configuration.

\section{* EXOTICISM IN TRANSLATION}

Unusual and non-traditional choice(s) from the thematic and linguistic expressive elements in TT1. This means a choice of elements which are typical of the TT1 culture. while developing an a-typical style (thematic and linguistic) for TT2. It also means a stylistic approximation of TT1 to the cultural parameters of TPI and RR I into TT2. An extreme application of exoticism has its counterpart in naturalization. Exoticism in translation is foremost a semiotic operation. However, this feature alone would not suffice to distinguish TT1 from TT2.

* EXPERIMENTAL SUB-SYSTEM OF TP2 AND RR2

The sum of inherited and individually acquired experience that serves as a background for a semiotic and expressive realization of TT 1 into TT2, as well as for RR2. 


\section{* EXPRESSIVE MECHANISMS IN TRANSLATION \\ 1. Expressive Configuration}

Systemic arrangement of elementary expressive categories of TT1 upon the basis of semantic oppositions. Fupressive Configuration is a paradigmatic aspect of style in TT2 (cf. Figure 1$)$.

2. Expressive Functionality

Provided there is a lack of formal correspondence of any elements, TP2 chooses a different element that is in expressive correspondence with the appropriate element from TTI into TT2. The expressive functionality of the translation is conditioned by a preservation of the semantic invariant of TT1. This functional principle is realized with certain expressive shifts in the process of choice of expressive alternatives. This means that the funclional principle is formally realized only to some or a limited extent.

3. Expressive Individualization

Translational transformation intensifying the unique expressive features of TT1, as well as TP2 $s$ individual propensities.

4. Expressive Inversion

Transfer of some elements of TT1 to a different position in TT2.

5. Expressive Levelling

The removal of unique expressive features of 111 into 12 .

6. Expressive Lexical Identification

Ascertainment of the expressive value of lexical elements in TT2 by means of a stylistic and semantic interpretation within the framework of the expressive configuration. The stylistic value is ascertained empirically and theoretically at the same time. In practice. Expressive Lexical Identific ation means the securing of stylistic affiliation on an intuitive level by TP2.

7. Expressive Line

Projection of expressive features of TT1 into TT2. The realization of the expressive line is stochastic, although preserving a certain invariant.

8. Expressive Loss

Impoverishment of the expressive structure of TT1. at times amounting to a complete loss of some expressive elements or lines in TT2.

9. Expressive Structure

Unique or standardized arrangement of the expressive features upon the basis of the selection that determines the communicative attitude. It is a syntagmatic realization of the style (Miko).

10. Expressive Substitution

Replacement of untranslatable expressive elements of TT1 with elements which approximate these in expressive value in TT2.

11. Expressile Thematization

Translational transformation stressing the characteristic expressive features of TT1 in TT2.

\section{* EXTERNAL-THEMATIC CONFIGURATIONS IN TRANSLATION}

Relation of the topical elements in the text to the cultural code that serves as a basis for the translator when choosing suitable equivalents for the cultural peculiarities of the text. They represent the sociocultural framework of the translator's decisions when naturalizing the topic.

* FACTORS OF CULTURE IN TRANSLATION

The ratio of elements representing TP1's cultural system to those typical in TP2's cultural system. In semiotic terms, this ratio may be expressed as an opposition of domestic vs. 
foreign factors of the cultural system. These can be realized in TT2 according to TP2's communicative attitude through either approximation or moving away from TT1 ( $c f$. Exoticism in Translation). This process of decision making is considerably influenced by TP2's cultural system and her/his expressive level.

* FREE tRANSLATION see OVERINTERPRETATION IN TRANSLATION.

\section{* FUNCTION OF TRANSLATION}

The manner in which a translation is realized with RR2. Also, according to the manner in which the function is realized, the following objectives of translation can be distinguished. However, these objectives may or may not be variably combined:

1. Informative, i.e. mediation of TT1 in RR2 and TT2 as an object to be received by specific or non-specific RR2.

2. Socio-cultural, i.e. translation as a factor in the sub-system of literary communication and, in its wider spectrum. in the system of social interactions.

3. Literary, i.e. translation as a manifestation of communication in a) the sub-system of literary communication built upon the perceived needs of RR2.

* GENERIC NOTION IN TRANSLATION

A general notion intended to characterize the universal nature of the translational process, as well as the difference among various types of translation according to their content and stylistic features and objectives (e.g. scientific, religious, literary, oral, written, etc.) (Ljudskanov).

\section{* HIGHER SEMANTIC AND CONTENT SYNTHESIS}

The enrichment of the intertextual invariant in its content and semantic layers through a metatextual process. The higher semantic synthesis represents the realization of implicit and potential meanings of the prototext into the metatext and their reverse influence on the prototext. The intertextual process is a transition in the enlargement and deepening of the prototext by the higher content analysis of the prototext and results in an enlargement of its metatext (Sabouk).

\section{* hISTORIZATION OF TRANSLATION}

Thematic and linguistic modification of TT2 as a whole or of its various levels. It is motivated by the codes of TT1, but not by anticipation of RR2's points of view (Holmes).

\section{* HISTORY OF TRANSLATION}

Modelling the translation process in the diachronic perspective. A history of translation may be regarded as a component in the process of literary history and, in this sense, as a part of a language's (national or intra- or inter-national) literary history. More specifically. a history of translation should include the elements of the Possible Model for a History of Translation. In this respect, a history of translation converges with literary comparison and its constituent literary parts such as aesthetic polyvalence, stylistics, etc.

1. A Possible Model for a History of Translation

A) Preparatory works for a history of translation:

A.1 Bibliographical lists of translations, statistics of manuscript, joumal, and book-form translations and their evaluation - according to the stratification of literary genres, authors, periods, and literatures.

A.2 Bio-Bibliography of translators and Bibliography of dictionaries of national-language translators. The differentiation of translator activities into TPI and TP2 when same person and when TP2 is specialist.

B) Praxeology of translation:

External conditions and socio-cultural preconditions of translator activity. 
C) The development of translation methods:

C.I The establishment of institutional translator programs

C.2 The formulation of a system of translation (process and text in the categories of SEAL)

C.3 The writing of histories of translation methods according to specific literary periods

D) The role and function of translation in the history of literature viewed as a system:

D.1 Translation in the systemic configurations of TT1, TPI. PT1. RR1, PPI, of TT2, TP2, PT2, RR1, and PP2, and of all possible variables between TT1 to PP1 and TT2 to PP2.

D.2 Translation in PPI and PP2 (i.e. meta-literature and literary education)

D.3 Translation within the parameters of the socio-cultural system of interaction. with focus on the relationship of literature to philosophy. religion, history, etc.

E) A Typology of national-language translation in particular periods in their comparison with other literatures.

* IDIOLECT (TP2'S IDIOLECT) see TP2'S POETICS

* INSINUATION TO RR2s IN TRANSLATION

Deliberate choice and introduction of expressive conventions familiar to RR2 in accordance with RR2's poetic choices, aesthetic values, and prejudices.

* INTERDISCIPLINARY RELATIONS OF TRANSLATION

Interdisciplinary complexity of the study of literary translation. representing the participation of related humanistic disciplines in creating theories of literary translation and their meta-language and taxonomy.

* INTERPRETATION

1. Sovlistic Interprotation in Translation

Analysis of stylistic means in the translation with respect to the stylistic qualities of TTI In TT2 it may be realized either intuitively or consciously. depending upon TP2 's stylistic competence and theoretical sophistication.

* INTER-TEMPORAL FACTOR IN TRANSLATION see TIME IN THE TEXT OF TRANSIATION

* INTERTEXTVALITY

Ability of TP2 to create and/or realize intertextual relations.

* INTER-SPATIAL FACTOR IN TRANSLATION

The difference between TTI and TT2 resulting from their different socio-cultural backgrounds. The tension between TT1 and TT2 is expressed by the semantic opposition of domestic vs. foreign factors (Lotman). The intensity of this intra- and/or inter-cultural tension is expressed by the coefficient of historical, anthropological, and psychological differences belween TT1 and TT2

* LINKINC;

1. Intertertual Continuation

Relations among texts shaped on the principle of dialectical opposition of affirmativity and controversiality. The assumed condition of intertextual continuation (linking) is the existence of intertextual invariant and the result of the continuation (linking) are the shifts which are an accompanying feature of the realization of the invariant in a new text. Continuation (linking) among texts is either a continuation among single texts or a continuation between a single text and a number of texts understood as a whole.

2. Complimentary (omtimuity (Linking) Intertextual continuity (linking) with textual supplements (notes, commentaries, epilogues) expounding invariant qualities of prototext. 
3. Imitative Continuity (Linking) A continuity (linking) giving the maximum preference to the presence of intertextual invariant in metatext: metatext shapes more clearly its semantic and stylistic resemblance with the prototext in the imitative continuity (linking). 4. Reducing Continuity (Linking) The relation between the two texts which either reduces or extends single levels of the text under the condition of preserving semantics of the intertextual invariant.

5. Selective Continuation (Linking) Intertextual relation, when the creation of the metatext is based on the principle of selection of certain elements.

6. Liquidation Continuity (Linking) Controversial relation to the prototext exhibiting the omission of the text as a whole. Liquidational continuity (linking) of one text with another is at the same time the expression of the interpretative standpoint and it can, consequently, serve as recipe directions.

7. Reproductive Continuation (Linking) Metatextual operation of the literary continuation aimed at the reproduction of the text following the principle of "direct speech," i.e. quotation, selection of quoted elements of the text, or, the whole texts (selection of poetry. anthology) following the principle of minimum deviation from the prototext.

8. Summarizing (ontinuation (Linking) Metatextual operation of literary education aimed at the reproduction of the text following the principles of "direct speech," i.e. resuming. summarizing up to the most extreme logical measure of condensation of the text in a bibliographical work.

\section{* INSTRUCTION FOR RR2}

Influence on the receiver through the use of meta-communication system in favour of various codes. Recipe is applied as an instruction or persuading. Instruction system may be realized through literary criticism, history of literature and theory of literature, making use of specific genres. These components of literary science, in addition to being recipe, fulfill also the modelling cognitive activity. Literary advertisement represents a specific aspect of the recipe, directed at engaging the receiver for literary metacommunication.

* INTERTEXTUAL INVARIANT

Nucleus of meaning common to two or more texts. Intertextual invariant comes into existence on the basis of interliterary continuity (linking). The original invariant of prototext is shifted during the creation of metatext. As a result of this process certain qualities of prototext and metatext are lost on the one hand and other qualities are subsequently gained (higher semantic and content synthesis).

\section{* INVARIABILITY OF MEANING IN TRANSLATION}

The invariant core of a text is represented by stable, basic, and constant semantic elements. Their existence can be demonstrated by semantic condensation. This core of standardized meanings makes TP2's or RR2's concretization, i.e. transformations or variants, possible. These imply changes which do not modify the core of meaning but influence only the expressive form.

* INVARIANT SEMANTIC CORE SEe SEMANTIC CONDENSATION IN TRANSLATION

* LANGUAGE

1. Language of Translation

The arrangement of linguistic elements in TT2 with respect to the correspondence on linguistic (phonemic, morphemic, lexical, syntactic) levels between TT1 and TT2.

2. Mediating Language in Translation

Grammatical, lexical, and stylistic sign configuration, serving TP2 as a tertium comparationis. It is a mediating factor upon the thematic and linguistic levels when evaluating the adequacy of the expressive configuration. 


\section{Source Language}

The language from which the literary message is translated.

4. Target Language

The language into which the message is translated.

\section{* LINGUISTIC GRATIFICATION}

The accidental occurrence of linguistic gratification in TT2. It is understood as the translation of elements in the language of TT1 into TT2 whereby a gratification of two linguistic structures occurs in TT2, i.e. a penetration of TT1's language structure(s) into the language of TT2.

\section{* LINGUISTICS OF TRANSLATION}

An arrangement of linguistic levels (organized hierarchically and subordinate to the functional principle) in the translation, including phonemic (graphemic), morphemic, lexical, syntagmatic, and syntactic levels. It also includes research of translation from this point of view.

\section{* LITERARY ADVERTISEMENT}

A kind of metacommunication activity within the framework of the system of literary culture which represents specific metatexts (notice, announcement and the like). The basic textual sign of metatexts of literary advertisement is semantic affirmity, and connected with it also expression affirmation which is exposed by taboos, that is, stylistic orders and prohibitions. Literary advertisement fulfills sometimes the function of persuasive functions of advertisement in favour of social, economic, and literary codes. The full development of this function in literary advertisement is inhibited by its aiming at TT2, which in turn hinders the application of critical elements in evaluation. Literary advertisement does not take into account the value context of another text, but creates a value for the work ad hos.

\section{* LITERARY COMMUNICATION}

Communicational linking in the literary sub-system between TTI to PP2.

* LITERARY EDUCATION

A system of literary metacommunication, the function of which is to mediate and to supply information about either TT1, TT2. or both and to issue instructions for its/their reception. Literary education is transmitted by specific texts. Genres of literary education are differentiated into mediating (summarizing, reproductive, and liquidating) advertisements - not only to present specific aspects such as a system of genres of the given literary historical period is included in the system of literary education but also tradition, i.e. the memory of the literary system. Literary education from RR2's point of view represents a "state" of tradition. It is a product of the literary system and at the same time also its new point of departure.

\section{* LOCALIZATION IN TRANSIATION}

The modification of thematic elements of TT1 into TT2 which refer to the location of the action. Its aim is to accommodate TT2 to RR2's socio-cultural and/or literary background.

\section{* MACRO-STYLISTICS IN TRANSLATION}

The level of higher semantic elements in the text (TTI and TT2), including sentence, supersentential formations (hypersyntax) and the notion of text as a whole. The text represented by thematic facts (action. time. place. protagonists, composition, etc.). 
* MEASURE

1. Full Measure in Translation and Adequacy of Translation see Equivalence

2. Saturated Measure in Translation see Overinterpretation in Translation

* METACOMMUNICATION

Secondary, derived communication; the function of metacommunication is development. or denial of invariant qualities of the prototext in the secondary, derived text, metatext.

* META-CREATION

Secondary, derivative literary creation, the impetus for which is to be found in another literary work. It is preceded by meta-linguistic (analytical) activity. Meta-creation in TT2 is a synthesis of TP2's absorption in the text-generating process.

* META-LINGUISTIC POSITION OF TP2

TP2 's analytical operation that aims at setting up rational criteria for evaluating TT1. Its purpose is to locate the invariant core of $\mathrm{TTl}$ and to evaluate the translation objectively as inter-literary communication. Thus, it acts as the chief influence on TP2's decisions in producing TT2.

\section{* META-LITERATURE}

Secondary, derivative text arising from the relation between texts. Meta-literature in a non-controversial form may also function in a relatively independent way from the viewpoint of RR2 (the knowledge of a prototype need not be assumed; on the contrary, it deliberately replaces the prototext). In literary communication, metaliterature in its controversial form assumes full knowledge of the prototext. Under certain conditions, metaliterature may become the source of further development of literature.

* METAPOEM

Refers to a derivative literary activity consisting in a modification of the original text (Holmes).

\section{* METATEXT}

The model of prototext: the way of realization of intertextual invariant between the two texts. The rules of this modelling are the text-formatting activity generated by the creator of metatext.

A) The principle aspects of the relation between prototext and metatext are the following: semantic. stylistic, axiological and those associated with TPI's strategy.

B) The ratio prototext: metatext can also be studied in its stylistic aspect according to the degree of homology between the proto- and metatext on the expressive level (affirmative and controversial linking). The stylistic aspect of the metatext is at the same time also an axiological aspect, since it embodies evaluation of the prototext, as well as its means of expression.

C) The study of metatext also involves an examination of TPI's strategy in linking his metatext to TT1. TT1 may decide either to conceal or to reveal her/his intention to draw on another text. The decision has the character of a style-forming act.

D) One can also enquire about the textual scope of the contact between proto- and metatext: does it involve only individual elements or levels of the text, or does it refer to the text as a whole.

E) The next step consists of an examination of the nature of the transformations which the prototext can undergo in the metatext (initiative continuity, selective continuity, reducing continuity and complementary continuity).

1. Affirmative Metatext

Agreeing, non-polemic continual (linking) metatext. The Affirmarive Metatext includes all the modes of intertextual continuation (linking) (i.e. imitative, selective, reduction, 
and complementary transformations). The dialectic element of the Affirmative Metatext is represented by its ability to present controversy in a changed context (quotational parody).

2. Auto-metatent

The prototext of TTI which is the work of the same author. Transition of intertextual invariant from the given text to another one within TTI of TPI can be represented either by the levels of the text or by the text as a whole.

3. Controversial Metatext

Negatively, polemically continuing (linking) metatext. The dialectical element of the Controversial Motatext is its partial ability to issue information about TT1.

4. Intentional Metatevt

Metatext expressing the primary intention of TTI's subject. When compared with the non-intentional metatext, it does not represent any intention to continuation (linking). The Intentional Melatext can represent either the programme on an individual or group basis. The indicator of the origin of the intentional metatext is represented primarily by the relation of subject to reality. the indicator of the origin of non-intentional metatext is represented by the relation of subject towards tradition and intertextual practices (accidental elements, allusion without quoting sources, etc.).

5. Secondary Metatext

Secondary, derived metatext, the "prototext" of which is not the original text, but metatext.

6. Subject of Metatert

Participation of the communication subject in intertextual continuity. This participation is the expression of TP I's strategy in creating TT1. The subject of metatext can manifest himself overtly or covertly, affirmatively or controversially, according to given levels of the text. The measure of this participation manifests itself in a dialectic offsetting of affirmative and controversial principles in continuity.

* MEMORY OF TP2'S SELFCTIONS

A "stock" of expressive conventions accumulated by TP2 during her/his activity of translation. The memory of TP2's solution( $s)$ is realized as TP2's expressive habits affects RR2's expectations.

\section{* METHOD OF TRANSLATION}

Depends upon TP2's individual relation with existing tradition(s) and with the prevailing factors of the literary system and the factors of aesthetic polyvalence, and comprises TP2's work in all its respects.

\section{* MICRO-STYLISTICS OF TRANSLATION}

Expressive arrangement of the lower. linguistic levels of TT2 in the course of translation, from phoneme to sentence.

* MODEL (STYIISTIC) IN TRANSLATION

Reproduction of stylistic features of TT1 in TT2. Basic rules concerning the stylistic disposition of expressive elements, their similarities and differences in the two languages. the degree of TP2's familiarity with them and her/his utilization of these determine her/his stylistic faithfulness.

\section{* MODEL OF COMPARISON IN TRANSLATION see MEDIATING LANGUAGE IN TRANSLATION}

* MODERNIZATION IN TRANSLATION

Thematic and linguistic modification of TT1 as a whole. Modernization in Translation is formulated in accordance with the assumed lastes of RR2 (Holmes). 
* NEUTRALIZATION OF THE RELATION OF ARCHITEXT TO METATEXT

The weakening of the dependence of the metatext on the prototext, resulting from metatextual variation. As a result of successive-simultaneous metatextual operations the prototext ceases to appear as a concrete point of departure for continuity. The position of the architext can be explained as a summation of concrete variants.

* NIVEAU (LEVEL)

1. Linguistic Level (Niveau) of Translation

Its acceptability to RR2 in terms of stylistic purity and linguistic correctness.

2. Literary Level (Niveau) of Translation

The degree to which the contemporary literary system has been mastered and further developed by TP2.

3. Socio-cultural Level (Niveau) of Translation

The potential ability of TP2 to reshape the cultural codes of RR2.

4. Stylistic Level (Niveau) of Translation

The degree to which the contemporary stylistic conventions of the RR2's language have been mastered and further developed in TT2.

* ONTOLOGY OFIIN TRANSLATION

1. Exrratextual Ontology

Reality depicted by means of a text.

2. Textual Ontology

Entering of poetic, social, psychological and other elements into the text through transformational processes (reflection of reality). In the text these elements are represented by thematic facts and mastering of a given form.

* OPERATIONS

1. Linguistic Operation in Translation

The search for and evaluation of correspondence between the elements of the language of TT1 and those of TT2.

2. Stylistic Operation in Translation

The search for and evaluation of the adequacy and plausibility of the stylistic and expressive features of TT2 which replace the corresponding features of TT1. The "mediating" code of TP2's stylistic operation is a functional arrangement of the basic expressive features of text.

* OVER-INTERPRETATION IN TRANSLATION

Tendentious interference by TP2. Usually, thematic and expressive elements are introduced into TT2 which do not exist in TT1. An interpretation of the "deep" structure of the text without taking into account the superficial level. Overinterpretation is characterized by an excessive prominence of the linguistic element of TT2 as well as by distortion of the content.

* POETICS OF TRANSLATION

1. TP2's Formulated Poetics

A set of experiences, opinions, and criteria which have been acquired by TP2 in the course of her/his activities and formulated in a generalized form. The TP2'S Formulated Poetics may be formulated in various ways, such essais, critical articles, etc. It is a part of the theoretical super-structure of the art of translation of a literary historical period, being a component of translational aesthetics. It may be regarded as part of the literary consciousness of its age. 


\section{TP2's Poetics}

The poetic idiolect, a system of TP2's expressive peculiarities seen from the angle of the current literary system or of the standardized translational method. The elements of this system are individual qualities characteristic of TP2 $\$$ s creative attitude.

* PRINCIPLISS

1. Historicizing Principle see Historization of Translation

2. Modernizing Principle see Modernization of Translation

* PROCESS OF TRANSLATION

A literary communicative activity where recoding from TT1 into TT2 takes place within the literary system. The Process of Translation is realized in phases as a process of decoding and encoding of the message by a process of "mediation." In literary translation it is the stylistic code that serves as the main factor of mediation. This results in recoding the message in TT2 and in delivering it to RR2.

* PROTOTEXT

Text, an object of intertextual continuity. Every text shows as a rule the ability of intertextual continuity. Realization of this possibility is a matter of the dynamics of the developmental process.

1. Quasi-metarext

The pretence that the texts of one's own making is somebody else's translations are taken for the "original works" (method of pseudonym). Quasi-metatent as a text is a result of the communication strategy of the TPI aimed at the exploitation of RRI's expectations of the metatext.

\section{* RECODING;}

The transfer of a text from one semiotic system into another. If the transfer is interlingual, recoding is termed translation. The notion of recoding is hierarchically higher than that of translation.

1. Dopth Recoding

A translation upon the depth level of text that harmonizes with both depth and surface structure of TTI. It is also a translation displaying deviations in the surface structure provided the depth structure is transferred in an adequate way into TT2.

1. Surface Recoding

A translation carried out upon the surface level of TT! without taking into account the depth structure of TTI (sub-interpretation).

\section{* RELATIVE MODERNIZATION OF TRANSLATION}

Topical, thematic, and linguistic modifications of TTI directed at its individual components and not at the text as a whole. These modifications are motivated by semantic and stylistic directives formulated from the RR2's point of view. They are realized by TP2 (Holmes).

\section{* SELECTION OF TEXT FOR TRANSLATION see TP2'S PROGRAMME.}

\section{* SEMANTIC CONDENSATION IN TRANSLATION}

A gradual formalization of semantic segments in TT2 which makes it possible to arrive at the basic invariant of the text.

* SEMANTIC INVARIANT OF TTI AND TT2

The semantic identity of elements in TTI and TT2.

* SEMANTIC AND STYLISTIC INSTRU CTIONS IN TTI

Structural features of TTI resulting from the conventional and unique arrangement of literary communicative syntagmatics (literary parole) that are obligatory for TP2 2 creation. 


\section{* SEMIOTICS OF TRANSLATION}

The semiotic nature of the translation process. Translation is, in relation to TP2's literary activity, a derivative, secondary activity. It is a meta-communicative act in relation to RR2. The semiotic aspect in translation is concerned with the differences met within the process of translation which are a consequence of a different temporal and spatial realization of TT2 (Even-Zohar).

* SERIALITY OF TRANSLATION SEe REPEATABILITY OF TRANSLATION

\section{* SHIFT}

1. Constitutive Shift in Translation

An inevitable shift that takes place in translation as a consequence of differences between the two languages, the two poetics, and the two styles of TT1 and TT2.

\section{Generic Shift}

A type of thematic shift implying a change in constitutive features of the text as a literary genre. The generic shift usually takes place on the level of the text's macro-stylistics and is accompanied by micro-stylistic shifts in the translation. The generic shift is characterized by various types of translational versions.

3. Individual Shift

A system of individual deviations motivated by TP2's expressive propensities and her/his subjective diolect.

\section{Negative Shift}

An incorrect solution of information caused by a misunderstanding of the translation. It may be motivated by unfamiliarity with the language or by a superficial interpretation of the TTl's structure. The negative shift may be characterized in TT2 as a "mistranslation" (sub-interpretation) of the TTI (a neglect of the depth structure of the topic).

\section{Thematic Shift}

A difference between the thematic facts of TT1 and TT2 which appears as a consequence of using different denotations. Favouring connotation to the detriment of denotation in the translation.

\section{* SOCIOLOGY OF TRANSLATION}

Exploration of the genesis and functioning of translation within the system of communicative interaction. This branch of sociology is interested in translation as a manifestation of social communication. It explores translation as a fact of social and cultural consciousness within the scope of institutions (publishing policy, cultural interrelations. etc.) and individuals (Even-Zohar).

\section{* STRUCTURAL TYPOLOGY OF TRANSLATION}

The classification of translation in terms of the stratification of text levels upon which the translation has been realized. A literary translation is not only realized upon a single text level but encroaches upon other levels as well. The exploration of translation according to the linguistic levels realized in the translation is a heuristic phase in the investigation of translation.

\section{* STYLE}

A unique and standardized dynamic configuration of expressive features in the text, represented by thematic and linguistic means. This configuration of expressive features depends on TP2's communicative attitude. The paradigmatic aspect of style is an expressive configuration while the syntagmatic aspect is represented by a specific arrangement of style in the text. 


\section{Individual Style}

An expressive arrangement of the text motivated by expressive propensities of the originator of the literary communication (translation).

2. Style of a Period

An expressive arrangement of the text in accordance with the contemporary factors of the literary system such as stylistic conventions, expectations and habits of RR2. With respect to the literary canon each text exerts an influence upon the literary conventions: it may change the literary canon and thus the expressive stylistic standard of that period.

3. Style in Translation

A relation of the stylistic arrangement of elements in TT1 to their stylistic counterpart in TT2 and their arrangement in TT1 without regard to linguistic and thematic correspondences.

* STYLISTICS

1. Stylistic Affiliation of Word

The expressive affiliation of a lexical unit into a stylistic layer according to its stylistic nature.

2. Stylistic Calque in Translation

Borrowing of ready-made expressive schemes from TT1 into TT2 where they are, as a rule, absent. This borrowing may occur either upon the macro- or the micro-stylistic level.

3. Stylistic Differences in Translation see Expressive Shiff in Translation.

4. Stylistic Paradigmatics see Expressive Configuration

5. Stylistic Syntagmatic's see Expressive Structure of Text.

* SUB-INTERPRETATION IN TRANSLATION

A partially realized measure of assembling TT2, provided no stylistic recoding is performed upon all the required levels of TT1. An interpretation of the text surface structure without taking into account its depth aspect (Čermák).

* SUBSTITUTION OF THEMATIC ELEMENTS IN TRANSLATION

A replacement of idiomatic and/or untranslatable elements of TT 1 with elements that are available to TP2.

\section{* SYNCHRONIC VIEWPOINT IN TRANSLATION}

Considering the translation within the framework of the literary system in which it was produced.

* SYSTEMIC INCLUSION OF TRANSLATION

Systemic Inclusion of translation refers to the theoretical and methodological perspective of the history and development of literature. It means the realization of the possible range of relationships of TT1 to PP2. Systemic Inclusion of Translation can be also demonstrated by the intersection of the internal developments of translation - the communicative interaction of TT1 with TT2 with the sum of configurations involving TP1 to PP2 with historical plyvalent aesthetics in a research model for a history of translation.

* TENDENTIOUS TRANSCRIPTION

Metatextual operation of literary education realized on the principle of reproductive relation to prototext. Tendentious transcription is a maximally similar model of proto-pattern, which can have various degrees, such as document of prototext, Iranscription, and, least adaptation of prototext. 


\section{* TIME IN THE TEXT OF TRANSLATION}

A communicative temporal dimension in translation resulting from the fact that there is a temporal gap between the creation of $\mathrm{TT} 1$ and that of TT2. The temporal aspect is projected into TT2 upon two basic levels: 1) Upon the level of the material substrate (grammatical tense): and 2) Upon the level of semiotic functions of the text (time as a cultural phenomenon). TP2 is concerned especially with the latter temporal dimension which represents its depth dimension in the text. In translation, this dimension is manifested through approximating the original time (historization) or through its withdrawing (modernization), which depends on TP2's communicative attitude.

* TOPIC AND COMPOSITION OF TRANSLATION

A higher level of the text and its arrangement in TT2.

\section{* THEME IN TRANSLATION}

The realization of cultural codes in TT2. Thematic text elements and composition usually pass from TT1 into TT2 without considerable changes. However, if such shifts occur. they are determined by socio-physical differences between the literary systems of TTI and TT2, as well as by TP2's effort to saturate interests of taste (thematic adaptation. localization, and actualization).

\section{* TRADITION}

The sub-system of Tradition includes A) Affirmation - a mechanism of abstract intertextual relations where these are realized by means of selection and arrangement in a given period and B) Contrariness - mechanisms where such as the restoring of lost or missing texts, the discovery of a new text, the delayed or precocious developmental realization of a text, the destruction of a text, the discarding of text. etc., occurs.

\section{A) Affirmation}

1. Calquing of Texts

Intertextual continuity (linking) with maximum overlapping of the invariant of prototext and metatext. Tendentious transcription of texts is of this kind, i.e. maximum similarity of the models with slight shifting in the metatext (the change of technique, material, etc.). Calquing is in question, for example, when architectonic reconstruction of cities, destroyed monuments is discussed (bringing together the spatial and plastic qualities and components of a modem structure with the original character of architectonic composition, including copying of style). It is partially involved when new structures are incorporated into a historical whole. Calquing of texts can either occur only once with closed developmental tendency, or, it can provoke a whole series in continuity (linking).

2. Conformity in Continuity (Linking)

The way of accordant, i.e. non-polemic continuity (linking), in which the intertextual invariant is not disturbed.

3. Covers Continuity

The strategy of the author in creating the metatext without explicit reference to the prototext. The deliberate concealment of relations with the prototext has its stylistic aspect in the increased idiovariability of the text.

4. Destruction of Text

The change of the original functions of structural elements of the prototext within the metatext; this change can take place through deformation of the original elements of the text or the whole body of the text. Formation of the oppositions of meaning and expression between prototext and metatext can be realized by preserving the original elements though in a different context, and their destruction can be effected. 


\section{Discarding of Text}

Blocking of intertextual continuity in view of a certain type of text. This blocking takes place as a rule in creating a new developmental structure, and gradually assumes a normative character.

6. Discovery of Nen Text

Incorporation of a text taken over from one in another system into systemic order (relations between literatures, between high art and low art) under the assumption that the TT2 fulfills an innovative role from the point of view of the development of art.

7. Innowation of Declined or Surpassed Structure

Emphasizing and including texts into a newly created aesthetic structure; the texts or the elements of texts previously surmounted or relegated to the periphery are innovated from the point of view of ascending structure. they should contain stimuli for further development.

8. Introduction of Texts without Development Perspective

Introduction of texts of surpassed aesthetic structure at the expense of the creative or stabilized canon, which from the developmental standpoint represents a newer quality.

\section{Montage}

Realization of a number of metatextual elements within one metatext. The original elements gain semantic and stylistic homogeneity in the new structure. Different periods approached the principle of montage and dealt with its technique in comparatively different ways. Certain schools either "preferred" this technique or "suppressed" it. Classicism: more difficult conditions for montage, avoiding any confrontation of foreign elements or absolutization of partial moments, settlement, minimum of phonic contrasts and contrasts of meaning: Romanticism: preference for montage in the ontology of time and space: Realism: limitation of the possibilities of non-interrupted existence of different elements, positivistic principles on similarity and continuity, on contextuality and continuity of separate orders of reality: Symbolism: orientation towards inner, concealed meanings, emphasis on the search for poly-semantics of denomination. non-conventional combinations.

10. Non-conformity in Continuiry

Ways of continuity utilizing controversial type of metatextual operations (discarding of a text, destruction of a text, etc.).

11. Covert Continuity

The strategy of the author in creating the metatext with explicit reference to the prototext. The deliberate and manifestational reference to the prototext has its stylistic aspect in the increased sociovariability of the text.

\section{Preciocious Development Realization of Text}

Introduction of a text which does not correspond to dominant aesthetic systems of norms and conventions. The precocious developmental realization of a text occurs when there are created reception - presuppositions for the receiver. There may occur an agreement between the delayed and precocious introduction of a text when the delayed text contains developmental stimuli for the change of the developmental structure to the structure of a higher quality.

B) Contrariness

1. Reconstruction of Texts

Intertextual continuity developing intertextual invariant in terms of stylistically related structural methods or sometimes, on the contrary, on the basis of contradictory methods.

2. Restoring of Lost or Missing Text

The modelling of developmental process of ant though substitution of lost or missing texts. Such a substitution has, as a rule, objective presuppositions, depending on the liter- 
ary system of a given period. If the substitution of texts in the process of development relates to texts which have not been preserved, then we speak of true substitution - a given metatext becomes a model of non-existing texts. False substitution involves texts when the forged texts are presented as originals. They become quasi-metatext of nonexisting prototexts.

3. Syntagmatic Aspect of Tradition

Arrangement and application of intertextual relations in a literary system against the background of the repertory of intertexual relations. The configuration of intertextual relations at a given period of development has a normative character. Every text by its existence falls in a certain way (affirmatively, controversially, or dialectically) into this system and, in turn, any text becomes an individual, unique, and unrepeatable projection of this system.

4. Translation of Scheme and its Re-Shaping

Transformational process preserving the basic invariant of thematic or composition levels of text. Such a scheme can be enriched or impoverished by transition from one developmental context to another.

* TRANSFORMATION IN TRANSLATION

A modification of language, theme, and style in TT2 through a violation of the equivalence principle.

\section{* TRANSLATABILITY}

The possibility of a structural and literary or functional and semantic, as well as expressive, replacement of the linguistic elements of TT1 with those in TT2. The functional replacement is achieved in TT2 by means of expressive shifts.

* TRANSLATION

Recoding a text during which its stylistic model is constructed. Translation is a stylistic (thematic and linguistic) model of TT1 and it is in this sense that the translational activity is an experimental creation.

1. Authorized Translation (Auto-translation)

The translation of an original work into another language by TP1. Due to its modeling relation to TT1, auto-translation cannot be regarded as a variant of TT1, but as a true translation. This follows from a change of the axiological as well as stylistic and linguistic field into which TTl enters (Finkel).

2. Compilatory Translation

TT2 realized upon the basis of several translations.

3. Concealed Translation

Transformations of the appropriate segments of TTl but where certain elements remain untranslated. In such a case the full realization of the translation does not take place. On the contrary, its incomplete as well as fragmentary nature is utilized functionally in order to activize the appropriate literary structure (Balcerzan).

4. Direct (Primary) Translation

A translation realized upon direct manipulating of TT1 by TP2.

5. Fictirious Translation

An author may publish his original work as a fictitious translation in order to attract readers and to realize her/his own literary program and thus it is subjectively motivated. In text theory. fictitious translation may be defined as quasi-metatext, i.e. a text that is to be accepted as a metatext. 


\section{Intersemiotic Translation}

A translation realized between two semiotic systems. This involves intersemiotic transformation, e.g. from the language of literature into that of film, or from the language of fine arts into that of music, etc.

\section{Intralingual Translation}

Transformations of the text or its elements within the framework of one linguistic system. It takes place upon the level of semantic synonymity (e.g. explanations in text, notes, etc.).

8. Intraliterary Translation

A translation realized within the same literature, usually from an older phase of literature into a new one. Intraliterary translation is a replacement of the linguistic, stylistic, and semiotic levels of TTI. From the point of view of the text-generating operations, there is distinction to be made between a tendentious transcription and a translation. The pragmatic motivation of intraliterary translation is to be sought in the communicative needs of literary texts as well as in the relationship of contemporary literature to the heritage of preceding literary periods.

9. Literal Translation

A translation of linguistic meanings in TT1 provided the possible stylistic equivalents are individuated. Literal translation is a result of preparatory metalinguistic (philological) activity and serves as a basis for TP2's creative activity.

10. Machine Translation

A translation made electronically with artificial intelligence. A programmed isomorphism of lexical elements of the linguistic system of TT1 and TT2.

11. Phonemic Translation

A translation realized dominantly upon the phonemic level of the text.

12. Polemical Translation

Intentional translation in which TP2's operations are directed against another translator's operations that are representative of a different or antagonistic conception (translation); TP2's operations are intended to unmask certain expressive or other topical tendencies in another translator's conception (or in that of TP1's ). The polemical translation is an affirmative-controversial metatext (Balcerzan).

13. Pseudotranslation see Fictitious Translation

14. Secondary Translation

Translational communication through the adoption of other translations. The communicative channel of secondary translation as a rule leads through literatures that are linguistically close.

15. Sequential Translation

A translation realized dominantly upon the sentence level, thus not achieving translational coherence. It may result in substandard iranslation.

16. Simultaneous Translation

A translation carried out simultaneously in time, usually orally.

17. Staightforward Translation

A transparent translation in which elements of the linguistic and thematic levels are replaced in a linear way, without taking into account their expressive values.

18. Substandard Translation

A translation characterized by a disregard for literary recoding from TT1 into TT2. On the textual level, substandard ranslation is manifested by subinterpretation, i.e., by the misunderstanding of ideological and aesthetic features of TT1, by a negative shift of expressive fealures from TT1 into TT2, or by an expressive nivelization of TT2. From 
RR2's point of view, substandard translation may cause a block of communicative channels, a depreciation and/or disqualification of TT1 and/or TPI.

19. Synchronic Translation

A contemporary translation of a contemporary text.

20. Textual Translation

A full translation in which TTI as a whole is subordinated to the translational process.

21. Verbal Translation

A translation realized dominantly upon the lexical level of the text.

* TRANSLATIONALITY

A communicative relationship in the the literary system between TP1 and RR2 who may or may not be aware that the literary communicate has been translated from TT1. Translarionality is a semiotic characteristic between TT1 and TT2 through to PP2.

\section{* TP2 (THE PRODUCER OF THE TRANSLATED TEXT)}

The communicant in the literary system who acts out the complex role of an interpreter of the information embedded in TTI. She/he is TTI's decoder, encoder as well its expedient into TT2.

1.TP2's Decision see TP2's Process of Decision

2. TP2's Expressive Typology

A classification of TP2's types in terms of their relations to complex stylistic values of TT1.

3. TP2's Process of Decision

A possibility of choice, preference, or rejection of expressive features during the act of creating the translational communicative upon the background of an expressive repertory realized by the translator. The possibility of choice of the expressive features is determined by TP2's expressive feeling and by the communicative situation in the literary system (Levý).

\section{TP2's Programme}

TP2's selection of TT1. Usually, the selection corresponds to prevailing literary, cultural, and social standards or it coincides with the ideological and aesthetic tendencies of the literary system of TP2. The TP2's Programme may either be ahead of the generally accepted canon or behind it. This is a result of TP2's individual taste. The TP2's Programme is generally a result of factors active in the literary system, i.e. TT1 to PP2.

5. TP2's Subject

A communication participant mediating TT1 to linguistically unprepared RR $2 \mathrm{~s}$. The TP2's Subject is projected into TT2 as a textual subject. It is realized as TP2's idiolect in the respective configuration of expressive shifts. The latter represents the TP2's poetics and is a correlate of the lyrical subject of TP1.

6. TP2's System of Deviations

A system of expressive shifts linked with TP2's expressive feeling. This may be also defined as TP2's poetics.

* TRANSLATIONAL SPECIFICATION see STYLISTIC INTERPRETATION IN TRANSLATION

* TRANSLATION THEORY

A discipline engaged in the systematic study of translation. Its task consists of modelling the translational process and text. 


\section{* TYPOLOGY OF EXPRESSIVE CHANGES IN TRANSLATION}

A classification of expressive shifts according to the levels of micro- and macrostylistics of the translation. The classification is based upon the stylistic unity of the elements of a work of an.

\section{* TYPES OF TRANSLATION}

The classification of translations according to their realization of type and function (e.g. scientific, literary, religious, legal, etc.).

* UNTRANSLATABILITY

A situation in which the linguistic elements of TT1 cannot be replaced or encoded adequately in structural, linear, functional, or semantic terms as a consequence of a lack of denotation and connotation in the language of TT2.

* VALUE

1. Actual Value of Translation see Axiology in Translation

2. Evolutionary Value of Translation

The diachronic parameters of translation.

3. Expressive Value of Translation

The sum of expressive qualities of TT2. The Expressive Value of Translation may be realized, with respect to TTI, upon the basis of a systematic artangement of expressive qualities in the expressive configuration and upon their realization in TT2. The expressive value of a text determines the style of translation as an organized set of invariant and variant elements.

\section{REFERENCES}

BALCERZAN, Edward and Zbigniew OSINSKI (1974) [1966): "Die theatralische Schaustellung im Lichte der Informationstheorie". Walter Kroll and Aleksander Flaker (Eds.). Literaturtheorretische Modelle und kommunikatives Systrem, Kronterg, Skriptor, pp. 371-411.

BARSCH, Achim, RUSCH, Gebhard and Reinhold VIF.HOFF (Eds.) (1994): Empirische Literaturwissenschaft in der Diskussiom. Frankfun/M.. Suhrkamp.

CHEVREL. Yves (1995): Compararive Literarure Trday: Merhods \& Perspectives, Elizabeth Farida Dahab, trans. Kirksville. The Thomas Jefferson University Press.

DIMIC. Milan V. (1992): "The Polysystem Theory", Irena R. Makaryk General Editor, Encyclopedia of Contemporary Literary Theory: Approsches. Siholars. Terms. Toronto, University of Toronto Press. pp. $151-155$

DIMIC, M. V. and M. K. GARSTIN (1988): "The Polysystem Theory: A Brief Introduction, with Bibliography", E. D. Blodgett and A. G. Purdy (Eds.). Prohlenss of Literary Reception/Prohlemes de reicepiion litierairc. Edmonton. Research Institute for Comparative Literature. University of Alberta, pp. 177-196.

EVEN-ZOHAR, Ilamar (199): Polysystem Studies, Special Issue Poetics Today, 11-1 (Spring), 268 p.

GORLEE. Dinda L. (1994): Semiotics and the Problem of Translation: With Special Reference to the Semiotics of Charles S. Pierce. Amsterdiam-Atlanta. Rodopi

GORP, H. van e't al (1991 a): "Empirische literatuurwetenschap". Lexicon van literaire termen, 5th ed., Leuven. Wolters, pp. 116-117.

GORP, H. van at al. (199/b): "Polysysteem (theorie)". Lexicon van literaire termen, 5th ed., Leuven, Wolters, pp. $312-313$

HERMANS. Theo (Ed.) (1985): The Manipulation of Literature: Studies in Literary Translation, LondonSidney, Croom Helm.

HOLMES, James S. (1988): Translated! Papers on Literary Translation and Transiation Studies, Amsterdam. Rodopi.

HOLMES. James S. (Ed.) (1970): The Nature of Translation: Essays on the Theory and Practice of Transiation. The Hague. Mouton/Bratislava. Slovak Academy of Sciences.

HOLMES. James S.. LAMBERT. José and Raymond van den BROECK (Eds.) (1978): Literature and Translation: New Perspectuves in Literary Studies, Leuven. Acco.

LIBA, P. (1978): Tende'neny prepis v systéme literárnéhe vadelania, Nitra, Pedagogicka Fakulta.

LEFEVERE. Andre (1992): Translating Literanure: Practice and Theory in a Comparative Literature Context, New York, MLA. 
MIKO, F. (1969): Estetika výrazu [The Aesthetics of Expression], Bratislava, SPN.

MIKO. F. (1970a): Texi a sryl [Text and Style], Bratislava. Smena.

MIKO, F. (1970b): "Pojecia socjologiczne w metajeziku analizy dziela literackiego" [Sociological Concepts in the Metalanguage of the Analysis of a Literary Work of Art]. J. Stawinski (Ed.), Problemy socjologii liferatury [Problems in the Sociology of Literature l, Wrochlaw, Ossolineum.

MIKO. F. (1972a): Maly v'vkladovy' slovnik vyrazovej sústavy (A Concise Dictionary of the Literary System of Expression]. Nitra. Pedagogocka Fakulta.

MIKO. F. (1972b): Ein kleines erklärendes Wörterbuch des Ausdruks-systems. Nitra. Pedagogicka Fakulta.

MIKO, F. (1973): Od epiky k lyrike. Stylistike priere:y literatürou (From the Epic to Lyrics, Stylistic Cross Sections of Literature], Bratislava. Tatran.

MIKO. F. (1978): The Programme of the Text, Nitra, Pedagogicka Fakulta

MIKO, F., ZAJAC, P.. POPOVIC, A., KOPÁL, J. and J. LIBA (1976): "Styl-kommunikacia-dielo" [The StyleCommunication-Literary Work of Art). Slavica Slovaca, 11-2, pp. 124-134.

MOŻEJKO, Edward (1979): "Survey: Slovak Theory of Literary Communication - Notes on the Nitra School of Literary Criticism", PTL - A Journal for Descriptive Poetics and Theory of Literoture, 4, pp. 37 1-384.

MOżEJKO. Edward (1993): "Nitra School". Irena R. Makaryk General Editor. Encyclopedia of Coniemporary Literary Theory: Approaches. Scholars. Terms. Toronto. University of Toronto Press, pp. 130-133.

POPOVIC, Anton (1967): "Die theoretischen Probleme der Ubersetzung", Literarur und Kritik, 2, pp. $611-617$.

POPOVIČ, A. (1968): Preklad a výraz [Translation and Expression], Bratislava. VSAV.

POPOVIC, A. (1970a): Strukturalismus v slovenskoj vede, Martin, Matica Slovenská.

POPOVIC. A. (1970b): "The Concept of 'Shift of Expression' in Translation Analysis", James S. Holmes et al. (Eds.). The Nature of Translation: Essays on the Theory and Practice of Translation. The Hague. Mouton / Bratislava, Slovak Academy of Sciences, pp. 78-87.

POPOVIC. A. (1971): Poetika umelecktho prekladu [The Poetics of Artistic Translation], Bratislava. Tatran.

POPOVIC, A. (1974a): Tedria metatexpov [The Theory of Metatext]. Nitra. Pedagogicka Fakulta.

POPOVIC A. (1974b): Umelecký preklad v CSSR [Artistic Translation in the CSSR]. Martin, MS

POPOVIC, A. (1975a): Teoria umeleckeho prekladu [Theory of Literary Translation], Bratislava, Tatran.

POPOVIČ. A. (1975b): Problémy literd́rnej metakomunikacie - teória metalextu [Problems of Literary Metacommunication - The Theory of Metatext], Nitra, KLKEM.

POPOVIC, A. (1976a): Lirerarne vadelanie. Srudie, Martin, Matica Slovenska.

POPOVIC'. A. (1976b): "Aspects of Metatext". Canadian Review' of Comparative Literalure/Revue Canadienne de Listerarure Comparce. 3-3, pp. 225-235.

POPOVIC, A. (1976c): Dic'fionary for the Analysis of Literary Translation. Edmonton, Deparment of Comparative Literature. University of Alberta.

POPOVIC. Anton (Ed.) (1973): Literárna komunikácia [Literary Communication], Marin, MS.

POPOVIĆ, A. (Ed.) (1975a): $O$ interpretácii umeleckého rexiu 5 [On the Interpretation of Artistic Texts 5]. Bratislava, SPN.

POPOVIC. A. (Ed.) (1975b): $O$ interpretocii umeleckeho textu 6 [On the Interpretation of Artistic Texts 6]. Bratislava, SPN.

POPOVIĆ. A. (Ed.) (1976): Pojmoslovie literarnej kommunikáce. Nitra. KLKEM.

SCHMIDT, Siegfried J. (1980): Grundril der Empirischen Literafurwissenschaft: der gesellschafiliche Mandlungsbereich Literatur. Braunschweig Wiesbaden. Vieweg.

SCHMIDT. Siegfried J. (1982a): Grundriß der Empirischen Literaturuissenschaff: zur Rekonstrukrion literalurwissenschaftlicher Fragestellungen in einer Empirischen Theorie der Literatur. BraunschweigWiesbaden, Vieweg.

SCHMIDT. Siegfried J (1982b): Foundarions for the Empirical Srudy of Literature: The Components of a Basic Theory, R. de Beaugrande, trans. Hamburg. Buske.

SCHMIDT, Siegfried J. (1991): Grundriß der Empirischen Literaturwissenschaft. mit einem Nachwort zur Taschenhuchausgabe. Frankfurt, Suhrkamp.

SCHMIDT. Siegfried J. (1992): "The Logic of Observation: An Introduction to Constructivism", Canadian Revien of Comparasive Literature/ Rev'ue Canadienne de Litterature Comparée. 19.3 (September), pp. 295. 311.

SCHMIDT, Siegfried J. (1994): Kognifive Autonomie und soziale Ordnung. Konstruktivistische Bemerkungen zum Zusammenhang von Kognition. Kommunikation. Medien und Kultur. Frankfun, Suhrkamp.

SEGERS, Rien T. (1994): "Durchbruch und Kanonisierung: Eine neue Provokation für die Literaturgeschichtsschreibung?" Achim Barsch, Gebhard Rusch. and Reinhold Viehoff (Eds.), Empirische Literarurn'sssenschuff in der Diskussion. Frankfurt. Suhrkamp, pp. 157-175.

TOURY, Gideon (1980): In Search of a Theory of Translatoon. Tel Aviv. The Porter Institute for Poetics and Semiotics. 
TÖTÖSY DE ZEPETNEK. Steven (1992): "Systemic Approaches to Literature - An Introduction with Selected Bibliographies". Canadian Review of Comparative Lirerature/Revue Canadienne de Litterature Comparée. 19-1/2, pp. 21-93.

TÖTÖSY DE 7EPETNEK. Steven (1993): "Empirical Science of Literature/Constructivist Theory of Literature". Irene Irena R. Makaryk General Editor, Encyclopedia of Contemporary Liserary Theory: Approaches. Scholars, Terms. Toronto, University of Toronto Press. pp. 36-39.

TÖTOSY DE ZEPETNEK, Steven (1994a): "Towards a Working and Cumulative Bibliography of Studies in the Systemic and Empirical Approach to Literafure", Steven Tötösy de Zepetnek (comp. and Ed.). IGEL New'sletter, 2, pp. 10-55.

TOTOSY DE ZEPETNEK, Steven (1994b): "Comparative Literature and Applied (ultural Studies, Or, a Report About the XIV"h Triennial Congress of the ICLA/AILC (University of Alterta, August 1994)". Canadian Review of Comparanve Literature/Rerue Canadienne de Litterature Comparée, 21-.3 (Seprember). pp. 469-49).

TÖTÖSY DE ZEPETNEK. Steven (1994c): "Comparative Literature and Systemic/Institutional Approaches to Literature: New Developments". Systems Research: The Official Journal of the International Federation for Systems Research, 11-2, pp. 43-57.

VISCO, Augostino (1992-199.3): "La Tradizione dello studio comparatistico in Slovacchia", I Quaderni di Gaia - Rivista di letterasure comparata, 5-6-7 (1992-1993), pp. 107-118.

WILPERT, G. von (1989): "Empirische Literaturwissenschaft", G. von Wilpen. Sachwiörterbuch der Literatur, 7th ed.. Stuttgart. Kroner, p. 233. 